\title{
Monitorowanie jakości usług publicznych problemem administracii samorządowej na przykładzie Słupska
}

\section{The Monitoring of Public Services Quality as a Problem of Local Government Administration - Stupsk Case Study}

\begin{abstract}
Streszczenie: Jakość usług publicznych świadczonych na rzecz społeczności lokalnych jest współcześnie wielkim wyzwaniem dla jednostek samorządu terytorialnego. Mieszkańcy, organizacje społeczne, przedsiębiorcy dokonują oceny działalności władzy samorządowej na podstawie poziomu zaspokojenia potrzeb publicznych. Gwarancją podnoszenia jakości tych usług jest stałe ich monitorowanie. W Polsce podejmuje się próby testowania, a nawet wdrażania innowacyjnych narzędzi do tego celu. Przedmiotem opracowania jest krótka charakterystyka usług publicznych w świetle ewolucji teoretycznych modeli administracji publicznej, omówienie narzędzi mogących służyć monitorowaniu tych usług oraz analiza praktycznego podejścia do tego zagadnienia na przykładzie Słupska. Głównym celem jest wskazanie, na przykładzie Słupska, na jakim poziomie znajdują się samorządy w zakresie wdrażania nowoczesnych instrumentów zarządzania. Wnioskowanie oparte zostało na interpretacji literatury, dokumentów strategicznych, materiałów źródłowych oraz na badaniu społecznym w postaci swobodnego wywiadu z pracownikami samorządowymi. W opracowaniu wykazano, że Słupsk i inne miasta testują nowoczesne narzędzia monitoringu jakości usług. Pomimo tego analizowane miasto nie zdecydowało się na wdrożenie jednego z nich. W ramach doskonalenia jakości usług publicznych zrezygnowano nawet ze standaryzowanych norm ISO na rzecz wypracowania własnego indywidualnego systemu zarządzania jakością usług publicznych.
\end{abstract}

\begin{abstract}
The quality of public services provided for local communities by the public administration units is today a big challenge for local government units. Residents, community organizations, businesses evaluate the activities of local government based on the level of satisfaction of public needs. Improving the quality of public services is possible through continuous monitoring. For this purpose attempts are made to make testing and even implementation of the innovative tools in Poland. The main subject of the study is a short description of public services in the light of the evolution of theoretical models of public administration, the description of tools form monitoring these services and the analysis of a practical approach to this issue as an example of Słupsk. The main objective is to identify, on the example of Słupsk, at what level implementation of modern management instruments are governments located. The reasoning was based on the interpretation of literature, strategic documents, source materials and social research in the form of interview free with the employees of the municipal office. The study demonstrated that Słupsk and other cities are testing the modern tools of monitoring the quality of public services. Despite that the analysed city decided not to implement one of them. As part of improving the quality of public services, the city gave up even on unified ISO standards in favour of developing their own individual quality management system of public services.
\end{abstract}


Słowa kluczowe: administracja publiczna; funkcja administracyjna; jakość usług publicznych; metody pomiaru; Słupsk

Keywords: administrative function; public administration; quality of public services; measurement methods; Słupsk

Otrzymano: 14 stycznia 2016

Received: 14 January 2016

Zaakceptowano: 6 czerwca 2016

Accepted: 6 June 2016

Sugerowana cytacja / Suggested citation:

Szymańska, W. (2016). Monitorowanie jakości usług publicznych problemem administracji samorządowej na przykładzie Słupska. Prace Komisji Geografii Przemysłu Polskiego Towarzystwa Geograficznego, 30(2), $171-185$.

\section{WSTĘP}

Jakość usług publicznych świadczonych na rzecz społeczności lokalnych przez jednostki administracji publicznej, ze szczególnym uwzględnieniem administracji samorządowej, staje się w dojrzałych demokracjach wymogiem koniecznym do efektywnego (z ekonomicznego punktu widzenia) i akceptowanego przez mieszkańców oraz podmioty prowadzące swoją działalność, zarządzania jednostką terytorialną.

Z uwagi na złożoność pojęcia „usługi publiczne”, w którym mieszczą się zarówno usługi administracyjne, społeczne, jak i techniczne, można wskazać przynajmniej dwa kierunki analizy. Po pierwsze, administracja samorządowa zwraca szczególną uwagę na obsługę administracyjną i w tym zakresie stara się podnosić „jakość” funkcjonowania urzędów. Po drugie, mieszkańcy intuicyjnie rozumieją usługi publiczne znacznie szerzej, odnosząc je przede wszystkim do „jakości swojego życia w mieście”. W tym kontekście podnoszenie jakości funkcjonowania administracji samorządowej jest ważne dla niej samej, ponieważ pozwala ona na zwiększenie skuteczności i efektywności planowanych i realizowanych zadań, a tym samym wzmacnianie efektów rozwojowych jednostki samorządu terytorialnego. Natomiast z punktu widzenia grupy użytkowników, czyli mieszkańców, organizacji społecznych, przedsiębiorców, może ona wzmocnić odczucie skuteczności sprawowania władzy poprzez wysoką jakość świadczenia usług publicznych na ich rzecz.

Przedmiotem rozważań jest wskazanie praktycznego podejścia jednostek samorządu terytorialnego do mierzenia i monitorowania jakości usług publicznych. Głównym celem jest powiązanie tego podejścia z naukową debatą o ewolucji teoretycznych modeli administracji publicznej zarówno z punktu widzenia teorii ekonomicznych i zarządzania, jak i geograficznych koncepcji funkcjonalnych.

Badania i analizy dotyczą przypadku miasta Słupska, jednostki samorządu terytorialnego o statusie administracyjnym miasta na prawach powiatu, które przez mieszkańców postrzegane jest jako zdegradowane administracyjne (po utracie statusu miasta wojewódzkiego w 1999 roku), z upadającą gospodarką i źle zarządzane (Szymańska, 2015). Istotną możliwością wpłynięcia na opinie mieszkańców jest rzetelne i transparentne sprawowanie władzy z aktywnym współuczestnictwem społeczności lokalnych. 
Nowy (nowoczesny) typ zarządzania administracją wymaga podjęcia działań pozwalających na zachowanie przejrzystości, ale także efektywności czy orientacji na system zadaniowy oraz sugeruje zastosowanie narzędziu ułatwiających stały wzrost jakości świadczonych usług publicznych. W artykule omówiono proces doskonalenia jakości tych usług w mieście i podejście samorządu do problemu monitoringu jakości tych usług.

Do realizacji celu zastosowano metody, które związane były z analizą i oceną literatury oraz dokumentów źródłowych i strategicznych Urzędu Miasta w Słupsku oraz z badaniem społecznym, w formie wywiadów swobodnych z pracownikami tego urzędu, m.in. z sekretarzem miasta, pracownikiem Wydziału Organizacji Urzędu, dzięki którym uzyskano sygnalną informację na temat kierunków działania dotyczących monitorowania jakości usług publicznych.

\section{USŁUGI PUBLICZNE}

Usługi publiczne w klasycznym ujęciu definiowane są jako te usługi, które służą osiąganiu celów wyższych, stanowiąc tym samym o istnieniu wspólnoty społecznej obywateli i służąc interesowi publicznemu. Za warunek konieczny sklasyfikowania jakiejś działalności jako usługi publicznej uznaje się nierywalizacyjny charakter jej konsumpcji oraz niemożność wykluczenia kogokolwiek z tej konsumpcji (Halcombe, 2005; Kożuch, Kożuch, 2011). Zakłada się przy tym nieokreśloność podmiotów, które mogą być dostarczycielem usług publicznych. Z natury definicyjnej wynika rola administracji publicznej, która powołana jest do realizacji usług publicznych lub przejmowania odpowiedzialności za ich realizację.

Tab. 1. Klasyfikacja współczesnych usług publicznych

\begin{tabular}{|l|l|}
\hline \multicolumn{1}{|c|}{$\begin{array}{c}\text { Kategoria usług } \\
\text { publicznych }\end{array}$} & \multicolumn{1}{c|}{ Rodzaje usług publicznych } \\
\hline \multirow{3}{*}{$\begin{array}{l}\text { Usługi i e-usługi } \\
\text { administracyjne }\end{array}$} & $\begin{array}{l}\text { Wydawanie dokumentów niebędących decyzjami administracyjnymi, } \\
\text { zezwoleniami, koncesjami. } \\
\text { Wprowadzanie do baz danych uzyskiwanych bezpośrednio od klientów. } \\
\text { Wydawanie zezwoleń i decyzji w trybie zgodnym z KPA. } \\
\text { Wydawanie zezwoleń i koncesji dotyczących działalności gospodarczej } \\
\text { Usługiamentowanej przez państwo. }\end{array}$ \\
\hline \multirow{3}{*}{ Usłue-usługi społeczne } & $\begin{array}{l}\text { Ochrona zdrowia. } \\
\text { Oświata i wychowanie. } \\
\text { Kultura. } \\
\text { Kultura fizyczna i rekreacja. } \\
\text { Pomoc i opieka społeczna. } \\
\text { Mieszkalnictwo. } \\
\text { Bezpieczeństwo publiczne. }\end{array}$ \\
\hline & $\begin{array}{l}\text { Transport - usługi i infrastruktura. } \\
\text { Zaopatrzenie w wodę i kanalizacja. } \\
\text { Gospodarka odpadami oraz utrzymanie czystości i porządku. } \\
\text { Cmentarnictwo. } \\
\text { Zaopatrzenie w energię (elektroenergetyka, gazownictwo, ciepłownictwo). } \\
\text { Zieleń publiczna. }\end{array}$ \\
\hline
\end{tabular}

Źródło: Kożuch, Kożuch (2011: 41) 
Administracja publiczna z funkcjonalnego punktu widzenia jest zespołem działań, czynności, przedsięwzięć organizatorskich i wykonawczych, prowadzonych na rzecz interesu publicznego przez różne podmioty, organy i instytucje, na podstawie ustawy i w określonych prawem formach (Izdebski, Kulesza, 2004: 79-84). Z tego powodu wydaje się, że administracja publiczna jest organizatorem i gwarantem realizacji pełnego zakresu usług publicznych. $Z$ tego punktu widzenia można je podzielić na trzy zasadnicze grupy (tab. 1): usługi administracyjne, usługi o charakterze społecznym oraz usługi o charakterze technicznym, wskazując jednocześnie na ich istotę i rolę, jaką odgrywają we współczesnych społeczeństwach (Kożuch, Kożuch, 2011: 40-41).

\section{USŁUGI PUBLICZNE W PROCESIE ZMIAN ZARZĄDZANIA W ADMINISTRACJI PUBLICZNEJ}

W teoriach ekonomicznych oraz zarządzania podkreśla się postępujący proces przekształceń w podejściu do zarządzania administracją publiczną oraz do wykonywania zadań, w tym świadczenia usług publicznych (m.in. Hausner, 2002; Krynicka, 2006; Kowalczyk, 2008; Ochnio, 2012; Bosiacki, Izdebski, Nelicki, Zachariasz, 2010). Impulsami warunkującymi proces ewolucji zmian w administracji są czynniki zewnętrzne, tj.: wzrost znaczenia usług w gospodarkach państw zachodnich, $w$ tym także w Polsce, zwiększająca się konkurencja między podmiotami gospodarczymi, wzrost oczekiwania konsumentów co do podnoszenia jakości usług, rozwój środków masowego przekazu i dostęp do nowych źródeł informacji, zwiększanie się świadomości politycznej i praw obywatelskich, wzrost udziału obywateli w sprawowaniu władzy publicznej poprzez tworzenie organizacji społecznych i stowarzyszeń (Ochnio, 2012).

Zmiany społeczno-gospodarcze spowodowały konieczność zwrócenia się po nowe sposoby i narzędzia w sprawowaniu administracji publicznej. Powszechnie dostrzega się proces przechodzenia od klasycznej administracji publicznej (Old Public Administration - OPA) przez zarządzanie publiczne (Public Management - PM), nowe zarządzanie publiczne (New Public Management - NPM) do współzarządzania publicznego (Public Governance - PG). Poszczególne typy sprawowania administracji publicznej wynikają, zdaniem L. Kowalczyka (2008), z relacji do systemu politycznego i społeczno-gospodarczego (tab. 2).

W Polsce dostrzega się elementy tych zmian, np. budowę nowych strategii zarządzania dla jednostek samorządu terytorialnego (Dryglas, 2014). Nie jest to jednak zmiana klasyczna, gdyż wynika z odmiennych uwarunkowań rozwoju społeczno-gospodarczego w krajach Europy Środkowo-Wschodniej (Marchewka-Bartkowiak, 2014). Według H. Krynickiej (2006) koncepcja nowego zarządzania publicznego oraz jej ewolucja -współzarządzanie publiczne - koncentruje się na: odbiorcy usług - jego potrzebach i oczekiwaniach, promowaniu konkurencji między usługodawcami, przekazywaniu kontroli społeczności lokalnej, decentralizowaniu kompetencji i wprowadzaniu zarządzania uczestniczącego. Skuteczne działanie wymaga połączenia wysiłków sektora publicznego, prywatnego i pozarządowego. J. Hausner (2002) umiejscawia w tym miejscu również konieczność stosowania zasady 3Es - economy, efficiency, effectiveness (oszczędność, 
skuteczność i efektywność). Stąd też rodzi się potrzeba wprowadzania elastycznych instrumentów oddziaływania pomiędzy podmiotami sektora publicznego. Do tego rodzaju narzędzi M. Ochnio (2012) wlicza metodę ugody, negocjacji, konsultacje społeczne, ale także soft law (miękkie prawo), tj. zalecenia, rekomendacje, kodeksy dobrych praktyk. Istotny jest nacisk na rozwój instrumentów kontroli działalności administracji. Do wdrożonych w Polsce tego typu narzędzi K. Marchewka-Bartkowiak (2014) zalicza: zarządzanie strategiczne, wieloletnie planowanie finansowe, budżet zadaniowy, kontrolę zarządczą, systemy zarządzania jakością czy budżet obywatelski (partycypacyjny).

Tab. 2. Proces zmian w administracji publicznej

\begin{tabular}{|c|c|c|}
\hline $\begin{array}{l}\text { Charakter administracji } \\
\text { publicznej }\end{array}$ & Zakres działania & $\begin{array}{c}\text { Stosunek do wykonywania } \\
\text { usług publicznych }\end{array}$ \\
\hline $\begin{array}{l}\text { Administracja publiczna } \\
\text { klasyczna/tradycyjna/stara } \\
\text { administracja } \\
\text { (Old Public Administration, OPA) }\end{array}$ & $\begin{array}{l}\text { Relacja z systemem prawnym } \\
\text { i politycznym - wykonywanie } \\
\text { przepisów ustaw i innych źródeł } \\
\text { prawa (weberowski model } \\
\text { biurokracji) }\end{array}$ & $\begin{array}{l}\text { Nie jest aktywnym dostawcą } \\
\text { usług publicznych }\end{array}$ \\
\hline $\begin{array}{l}\text { Zarządzanie publiczne } \\
\text { (Public Management, PM) }\end{array}$ & $\begin{array}{l}\text { Relacja z gospodarką rynkową - } \\
\text { otwarcie administracji publicznej na } \\
\text { koncepcje zarządzania, nowe techniki } \\
\text { komunikacji, zorientowane na interes } \\
\text { publiczny zgodnie z prawem }\end{array}$ & Usługi administracyjne \\
\hline $\begin{array}{l}\text { Nowe zarządzanie publiczne } \\
\text { (New Public Management, NPM) }\end{array}$ & $\begin{array}{l}\text { Relacja z gospodarką rynkową - } \\
\text { zorientowana na osiąganie efektów } \\
\text { ekonomicznych i społecznych } \\
\text { przy ograniczonym nastawieniu } \\
\text { na nakłady, wprowadzanie } \\
\text { mechanizmów rynkowych }\end{array}$ & $\begin{array}{l}\text { Koncentracja na kierowaniu } \\
\text { zamiast na świadczeniu } \\
\text { usług, zmniejszanie } \\
\text { kosztów świadczenia usług, } \\
\text { elastyczność, innowacyjność, } \\
\text { przedsiębiorczość, } \\
\text { apolityczność }\end{array}$ \\
\hline $\begin{array}{l}\text { Współzarządzanie publiczne/ } \\
\text { zarządzanie współuczestniczące } \\
\text { (Public Governance, PG) }\end{array}$ & $\begin{array}{l}\text { Relacja ze społeczeństwem } \\
\text { obywatelskim - nowa forma władzy } \\
\text { publicznej obejmuje różne poziomy } \\
\text { terytorialne i aktorów poprzez } \\
\text { partnerstwo, negocjacje i powiązania } \\
\text { horyzontalne - w warunkach } \\
\text { rosnących oczekiwań i złożoności sił } \\
\text { społecznych }\end{array}$ & $\begin{array}{l}\text { Zadania publiczne } \\
\text { powierza się podmiotom } \\
\text { ze sfery społeczeństwa } \\
\text { obywatelskiego, władza } \\
\text { zachowuje odpowiedzialność } \\
\text { za dostarczanie usług } \\
\text { publicznych }\end{array}$ \\
\hline
\end{tabular}

Źródło: opracowanie własne na podstawie Kowalczyk (2008)

\section{USŁUGI PUBLICZNE W NOWYCH GEOGRAFICZNYCH KONCEPCJACH FUNKCJONALISTYCZNYCH}

Funkcjonalne ujęcie zjawisk społeczno-gospodarczych w geografii ma długą i bogatą tradycję. Prezentację interpretacji koncepcji strukturalno-funkcjonalnych przedstawił w geografii miast A. Suliborski (2010). Autor samą funkcję, w kontekście teoretyczno-metodologicznych rozważań, traktuje jako funkcję działań miejskich, czyli pewną strukturę gospodarczą, która składa się z różnego rodzaju instytucji wytwarzających dobra materialne i usługi (Suliborski, 2010: 68). W tym ujęciu usługi publiczne stanowią część 
struktury funkcjonalnej jednostek samorządu terytorialnego i mają cechy czynnika rozwoju lokalnego (Domański, 2000; Kaczmarek, 2005; Parysek, 1997; Wojtasiewicz, 1997).

Funkcjonalne znaczenie usług publicznych można zauważyć już w klasycznych teoriach strukturalno-funkcjonalnych, gdzie funkcja ujmowana jest jako kategoria ekonomiczna, np. ośrodków centralnych Christallera czy bazy ekonomicznej. Nowe spojrzenie, z uwzględnieniem czynnika humanistycznego, prezentują wypracowane na gruncie polskiej geografii miast koncepcje: instytucjonalnego zorganizowania miasta (Szajnowska-Wysocka, 1995), realistycznego ujęcia dualizmu zjawisk osadniczych (Maik, 1992) czy funkcji miejsca (Suliborski, 2001).

Pierwsza z nich najbardziej nawiązuje do klasycznych ujęć funkcji. Głównym założeniem jest określenie układu instytucji w mieście, który wyraża istotę procesu zintegrowania społeczeństwa i dóbr materialnych. Zachowania instytucjonalne mieszkańców określają ich znaczenie dla funkcjonowania jednostki. Koncepcja realistycznego ujęcia dualizmu zjawisk osadniczych zwraca szczególną uwagę na łączenie w jedną całość zjawisk i organizacji występujących na wielu poziomach, z uwagi na istnienie złożoności rzeczywistości. Zjawiska ponadjednostkowe wyjaśniane są w myśli holistycznej, natomiast dla poziomu indywidualnych zjawisk konieczne jest uwzględnienie interpretacji humanistycznej. Uzasadnia to zaspokajanie potrzeb człowieka wg racjonalności działania podmiotów wykonujących określone zadania, w tym też usługi publiczne. Podobnie wielopoziomowo postrzegana jest koncepcja funkcji miejsca, w której wyróżnia się cztery atrybuty funkcjonalne: formę (funkcję użyteczności), eksploatację (funkcję działania), społeczną percepcję (funkcję postrzegania) i społeczne znaczenie (funkcję znaczenia) (Suliborski, 2001).

W koncepcjach tych świadczenie usług publicznych oraz społeczne odczuwanie ich jakości jest elementem postrzegania jednostkowego na poziomie miasta i powinno być analizowane przy określaniu klasyfikacji funkcjonalnej oraz czynników rozwoju.

\section{DOSKONALENIE USŁUG PUBLICZNYCH}

Teoretyczne podejścia, zarówno ze strony teorii ekonomii i zarządzania, jak i ze strony funkcjonalistycznych teorii geograficznych, kierują swoją uwagę na praktyczne możliwości zastosowania doskonalenia usług publicznych. Doskonalenie to może być realizowane w dwojaki sposób: poprzez zwiększenie dostępności tych usług oraz poprzez poprawę ich jakości (Ochnio, 2012).

Nowoczesne podejście do wykonywania zadań administracji publicznej, w tym świadczenia usług publicznych, wymaga wdrożenia instrumentu monitoringu i podnoszenia jakości. Współcześnie w Polsce nie występuje zbyt wiele narzędzi, które gwarantowałyby sprawne zarządzanie usługami publicznymi i doskonalenie ich jakości. Jak podają wyniki badania przeprowadzonego w 2010 roku na zlecenie Ministerstwa Spraw Wewnętrznych i Administracji ${ }^{1}$, jedynie 50\% jednostek samorządu terytorialnego

\footnotetext{
${ }^{1}$ Raport końcowy Badanie ewaluacyjne wsparcia udzielonego administracji samorzq̨dowej w ramach działania 5.2 Wzmocnienie potencjału administracji samorządowej Programu operacyjnego kapitał ludzki 2007-2013 (2010). Warszawa: ASM Centrum Badań i Analiz Rynku (materiał powielany), 81-83. Za: Rogala, Kusterka-Jefmańska, Chojecka, Koch-Mitka (2012).
} 
wykorzystuje monitoring do badania satysfakcji klientów (im większa jednostka samorządowa, tym częściej), 50\% stosuje budżet zadaniowy (działanie nie jest obowiązkowe), 15\% bierze udział w systemie analiz samorządowych (SAS), 25\% stosuje system zarządzania jakością (najczęściej ISO 9001), około 60\% prowadzi konsultacje społeczne (głównie w zakresie zagospodarowania przestrzennego), 75\% zleca realizację zadań publicznych organizacjom pozarządowym (najczęściej w kwestiach związanych ze sportem, kulturą oraz integracją społeczną), niecałe $8 \%$ realizuje zadania publiczne w oparciu o partnerstwo publiczno-prywatne (Rogala, Kusterka-Jefmańska, Chojecka, Koch-Mitka, 2012).

Wydaje się, że proces budowy sprawnego systemu zarządzania administracją publiczną, w tym monitorowania jakości usług publicznych, jest ciągle w fazie projektowania i testowania.

\section{WYBRANE SYSTEMY MONITORINGU JAKOŚCI USŁUG PUBLICZNYCH}

\section{System Analiz Samorządowych (SAS)}

SAS jest jedynym systemem monitoringu jakości zarządzania lokalnymi zadaniami publicznymi w krajach Europy Środkowo-Wschodniej zaprojektowanym jako system zbierania i udostępniania danych umożliwiający dokonanie porównań z innymi jednostkami samorządu terytorialnego. SAS został opracowany przez Związek Miast Polskich w 1999 roku, ale od 2008 roku w jego rozwój włączyły się Związek Powiatów Polskich i Związek Gmin Wiejskich RP (Glińska, 2009). To pionierskie w Polsce przedsięwzięcie dostarcza informacji na temat monitoringu oraz benchmarkingu w oparciu o dane pochodzące ze statystyki publicznej w zakresie: demografii, finansów, podstawowych wiadomości statystycznych, współpracy z organizacjami pozarządowymi oraz zrównoważonego rozwoju. Istotniejsze wydają się informacje pochodzące z monitoringu usług publicznych, które zbierane są z jednostek samorządowych współpracujących w systemie. Dotyczą one efektywności energetycznej, kultury, pomocy społecznej, oświaty, transportu, usług komunalnych, komunalnej gospodarki mieszkaniowej, projektu „Kompetentny urząd”. Niestety, zainteresowanie tym projektem, jak i aktywne w nim uczestnictwo, jest niewielkie. Jak wynika z zaproszenia Związku Miast Polskich z 2 czerwca 2015 roku, do wzięcia udziału w kolejnym cyklu badań, dotychczas w projekcie uczestniczyło 70 miast polskich², co stanowi niecałe $23 \%$ gmin miejskich i tylko 7,6\% miast (uwzględniając miasta w gminach miejsko-wiejskich) ${ }^{3}$.

\section{Program Rozwoju Instytucjonalnego (PRI)}

PRI jest narzędziem mającym służyć poprawie sprawności wykonywania zadań publicznych przez jednostki samorządu terytorialnego. Metoda PRI skierowana była

\footnotetext{
${ }^{2}$ Pozyskano z http://www.sas24.org/dokumenty-formularze/Zaproszenie\%20do\%20badan\%20 SAS_2014.pdf

${ }^{3}$ W 2015 roku w Polsce było 915 miast, w tym 611 w gminach miejsko-wiejskich. Podział terytorialny, Podział administracyjny, sieć osadnicza, Bank Danych Lokalnych, Warszawa: GUS. Pozyskano z https://bdl. stat.gov.pl/BDL/dane/tablica
} 
głównie do gmin wiejskich i małych miast, przy zastrzeżeniu, że podejście to może być z powodzeniem stosowane w innych jednostkach samorządowych. System oceny odbywa się poprzez ocenę zdefiniowanych dziewięciu obszarów zarządzania: (1) zarządzanie strategiczne i finansowe, (2) organizacja i funkcjonowanie urzędu, (3) zarządzanie kadrami, (4) usługi publiczne, (5) partycypacja społeczna i stymulowanie rozwoju społecznego, (6) stymulowanie rozwoju gospodarczego, (7) zarządzanie projektami, (8) współpraca między jednostkami samorządu terytorialnego, (9) etyka i zapobieganie zjawiskom korupcji. W obszarze „usługi publiczne” program zaleca stworzenie i aktualizowanie katalogu usług, w którym deklarowane są określone standardy. Odpowiedzialność za dostarczanie usług publicznych o zdeklarowanej jakości obliguje do stałego jej kontrolowania, tak aby najskuteczniej wywiązywać się z opublikowanego katalogu (Duda i in., 2004).

\section{Wzorcowy system regionalny monitoringu jakości usług publicznych i jakości życia (WSRMJUPiJż)}

Wypracowany przez Instytut Badań nad Gospodarką Rynkową innowacyjny system monitorowania jakości usług publicznych realizowany był w czterech gminach województwa pomorskiego: Gdańsku, Słupsku, Stegnie i Czarnej Wodzie w okresie od 1 listopada 2010 roku do 30 czerwca 2015 roku. Istotą projektu było stworzenie zintegrowanego systemu mierzenia jakości usług publicznych i jakości życia, wzbogaconego o platformę debaty (Pomorska Sieć Dialogu „Usługi publiczne”), dotyczącej interpretacji wyników i sposobu ich wykorzystania. Celem było dostarczenie zarówno twardych, jak i miękkich narzędzi monitoringu, w postaci list i kart mierników, opisu metodologii oraz możliwości ich wdrażania z wykorzystaniem narzędzi IT, przy umiejętności właściwej interpretacji wskaźników (Michalski, 2013).

Wśród korzyści z zastosowania tego systemu na szczeblu gminnym i powiatowym wymieniano: usprawnienie działań administracji i dopasowanie do potrzeb mieszkańców, zwiększenie przejrzystości funkcjonowania władz i uspołecznienie procesu zarządzania sprawami publicznymi oraz możliwość porównania się z innymi jednostkami samorządu terytorialnego. Na szczeblu wojewódzkim wymieniano dodatkowo korzyści bardziej obiektywnego programowania rozwoju województwa, uwzględniającego lokalne i subregionalne zróżnicowania jakości usług publicznych oraz warunków, poziomu i jakości życia (Czerwińska i in., 2014).

\section{Monitorowanie jakości usług publicznych jako element zintegrowanego systemu zarządzania jednostkami samorządu terytorialnego}

Realizowany we współpartnerstwie przez samorządy miasta Poznania i Krakowa innowacyjny projekt obejmuje monitorowanie 15 dziedzin, w tym: budżet zadaniowy, wieloletnią prognozę finansową, strategię rozwoju, system ewidencji księgowej, zarządzanie ryzykiem, metody i narzędzia badania wskaźników jakości życia i jakości usług publicznych, konsultacje społeczne, wdrożenie aplikacji informatycznej klasy Business Intelligence (Rogala, Kusterka-Jefmańska, Chojecka, Koch-Mitka, 2012). Jest to najbardziej komplementarny projekt, którego zastosowanie zbliżyłoby w niemal pełnym 
zakresie funkcjonowanie administracji samorządowej do modelu Good Governance, z pełnym wachlarzem metod i narzędzi monitorujących i doskonalących świadczenie usług publicznych.

\section{DoŚWIADCZENIA SŁUPSKA W BADANIU JAKOŚCI USŁUG PUBLICZNYCH}

Słupsk, miasto na prawach powiatu, w 1999 roku utraciło nie tylko prestiżową, ale postrzeganą jako ważną ekonomicznie, funkcję administracyjną miasta wojewódzkiego. Postrzeganie utraty funkcji administracyjnej utożsamiane jest ze wszystkimi negatywnymi zmianami, jakie miały tu miejsce od ponad 15 lat. Badania prowadzone w byłych miastach wojewódzkich regionów nadmorskich pokazują, że ponad $60 \%$ mieszkańców wszelkie niepowodzenia miasta (gospodarcze, społeczne) utożsamia z utratą funkcji administracyjnej. Pomimo takiego osądu mieszkańcy w kontekście złej sytuacji na rynku pracy (zamykanie przedsiębiorstw) częściej doszukują się przyczyny porażki w niewłaściwym zarządzaniu miastem niż jako konsekwencji utraty rangi administracyjnej (Szymańska, 2015). Z punktu widzenia samorządu lokalnego zapewnienie mieszkańcom transparentności wykonywanych usług publicznych, stałe podnoszenie ich jakości oraz włączenie mieszkańców w proces decyzyjny, może znacznie zmienić postrzeganie miasta i nastawienie do samorządu.

Poziom oceny systemu monitorowania jakości usług publicznych w Słupsku został dokonany przed przystąpieniem do Wzorcowego systemu regionalnego monitoringu jakości usług publicznych i jakości życia. Ocena ta została zawarta w rozdziale IV raportu - Krajowe i zagraniczne doświadczenia w zakresie badania jakości usług publicznych i jakości życia, autorstwa Wojciecha Szulca (pełnomocnika ds. zintegrowanego systemu zarządzania Urzędu Miasta w Słupsku). Z głównych wniosków tej oceny należałoby przytoczyć kilka, które wyraźnie charakteryzowały sposób zarządzania miastem. (1) Miasto nie posiadało jednolitego systemu monitorowania jakości usług publicznych i jakości życia. (2) Pomiar jakości usług publicznych związany był z dwoma obszarami aktywności, tj. funkcjonowaniem zintegrowanego systemu zarządzania (ZSZ) opartego na normach ISO oraz opracowywaniem i realizacją strategii miejskich. (3) Mierniki procesów zintegrowanego systemu zarządzania pozwalały na ocenę, utrzymanie ciągłości, powtarzalności i efektywności działalności Urzędu Miasta jako jednostki organizacyjnej (nie mierzyły jakości usług publicznych jako całości). (4) Pomiary jakości usług publicznych związane były z kwerendą danych wejściowych do opracowania dokumentów strategicznych, takich jak audyt zrównoważonego rozwoju (136 wskaźników) oraz wskaźniki na potrzeby strategii: m.in. Strategii transportowej miasta Słupska (11), Strategii turystycznej miasta Słupska (4 + badanie ankietowe). (5) Wyniki pomiarówjakości usług publicznych wykorzystywano głównie do przygotowania dokumentów strategicznych oraz do poprawy pracy organizacyjnej Urzędu. (6) Prowadzone pomiary nie wskazywały obszarów usług publicznych wymagających największej interwencji.

W wyniku prowadzenia projektu Wzorcowego system regionalnego monitoringu jakości usług publicznych i jakości życia dla Słupska opublikowano kilka raportów ${ }^{4}$,

${ }^{4}$ Publikacja raportów w ramach prowadzonego projektu jest dostępna na stronie http://monitoring. ibngr.pl/bank-wiedzy/. Najważniejsze z nich dotyczące monitoringu jakości usług publicznych to: Wstępne 
w których zawarte zostały najistotniejsze wnioski z zastosowanych narzędzi oceny. W ostatnim raporcie zanotowano wiele wniosków wraz z rekomendacjami, które wskazywałyby na konieczność poprawy jakości świadczonych usług publicznych, m.in. w zakresie obsługi Urzędu Miasta, usług związanych z pomocą społeczną, bezpieczeństwem, oświatą i kulturą.

Po analizie wykazanych wyżej materiałów w Urzędzie Miasta w Słupsku przeprowadzono rozmowy z pracownikami, tj. sekretarzem miasta - Iwoną Wójcik i pracownikiem Wydziału Organizacji Urzędu - Katarzyną Zabawą, na temat badania jakości usług publicznych w Słupsku oraz wykorzystania analiz przeprowadzonych w ramach powyższego projektu. Dodatkowo zapoznano się z dostępnymi w Biuletynie Informacji Publicznej materiałami dotyczącymi: organizacji Urzędu Miasta, poziomu świadczenia usług publicznych, dokumentami strategicznymi, miejscowymi aktami prawnymi i innymi mogącymi przybliżyć system monitorowania i doskonalenia usług publicznych w Słupsku. Z przeprowadzonej analizy wynika, że obecnie nadal nie istnieje system monitorowania jakości usług publicznych w mieście Słupsku. Do grudnia 2014 roku Urząd Miasta w Słupsku prowadził swoją działalność i monitorował jakość na podstawie systemu zarządzania jakością (SZJ). Certyfikowany system zapewniał zgodność z międzynarodowymi normami PN-EN ISO 9001:2009, PN-EN ISO 14001:2005 oraz PN-N-18001:2004, a wcześniej z normą PN-EN ISO 9001:20015. Z chwilą przyjęcia systemu zarządzania jakością powołano stanowisko pełnomocnika ds. zintegrowanego systemu zarządzania w Urzędzie Miasta w Słupsku6. Wraz ze zmianą władz samorządowych w 2014 roku zostały też zmienione zasady pracy urzędu. W listopadzie 2015 roku wprowadzono nowy regulamin organizacyjny Urzędu Miasta w Słupsku który nakładał na wydziały merytoryczne obowiązek prowadzenia konsultacji i dialogu społecznego w zakresie swojej działalności, znosząc jednocześnie dotychczasowe normy proceduralne dotyczące katalogu świadczonych usług publicznych. W uzasadnieniu wprowadzenia zmian pojawił się m.in. punkt 3., który informuje, że nastąpiło: „wykreślnie rozdziału VII Zintegrowany system zarządzania w związku z rezygnacją ze zintegrowanego systemu zarządzania certyfikowanego przez instytucje zewnętrzne. Nowy system zarządzania urzędem będzie wprowadzony odrębnym zarządzeniem Prezydenta Miasta Słupska".

Według przyjętej koncepcji monitorowanie jakości będzie się opierało na rozbudowanej demokracji obywatelskiej, transparentności działalności oraz dialogu społecznym, przy współpracy z organizacjami pozarządowymi, a procedury, monitoring

wyniki wdrożenia wzorcowego sytemu monitoringu jakości usług publicznych $w$ powiecie grodzkim Słupsk w 2012 r. - sierpień 2013; Szkoła w percepcji uczniów - wynik badań ankietowych uczniów w gminie miejskiej Słupsk - kwiecień 2013; Jakość usług publicznych i wybranych aspektów funkcjonowania miasta Słupsk. Wyniki sondażu opinii mieszkańców - kwiecień 2013; Szkoła w percepcji uczniów - wyniki badań ankietowych uczniów w gminie miejskiej Słupsk (drugie badanie) - czerwiec 2014; Jakość usług publicznych i wybranych aspektów funkcjonowania miasta Słupsk w 2013 roku. Wyniki sondażu opinii mieszkańców - wrzesień 2014; Wyniki wdrożenia wzorcowego systemu monitoringu jakości usług publicznych, w mieście na prawach powiatu Słupsk w 2013 r. (drugi pomiar) - wrzesień 2014.

${ }^{5}$ Zarządzenie nr 782/SZJ/09 Prezydenta Miasta Słupska z 19 października 2009 roku.

${ }^{6}$ Zarządzenie nr 1267/GPM/2012 Prezydenta Miasta Słupska z 4 grudnia 2012 roku.

${ }^{7}$ Zarządzenie nr 844/0U/2015 Prezydenta Miasta Słupska z 25 listopada 2015 roku. 
i kontrola jakości będą się opierały na systemie wypracowanym przez Urząd Miasta, który na chwilę obecną jest w fazie tworzenia. Płynne przechodzenie do nowych rozwiązań powoduje, że obecnie nadal obowiązuje katalog procedur zgodnych ze standardami ISO. Obejmuje on 258 usług/procedur przypisanych do realizacji przez wydziały merytoryczne urzędu (tab. 3) i koncentruje się wokół 62 typów zdefiniowanych tematycznie spraw.

Tab. 3. Liczba usług (procedur) wg wydziałów Urzędu Miasta w Słupsku w 2015 roku

\begin{tabular}{|l|l|c|}
\hline Lp. & \multicolumn{1}{|c|}{ Nazwa wydziału } & $\begin{array}{c}\text { Liczba udostępnionych } \\
\text { procedur }\end{array}$ \\
\hline 1 & Miejski Rzecznik Konsumentów & 1 \\
\hline 2 & Biuro Prezydenta Miasta & 2 \\
\hline 3 & $\begin{array}{l}\text { Pełnomocnik Prezydenta Miasta Słupska ds. profilaktyki } \\
\text { i rozwiązywania problemów alkoholowych }\end{array}$ & 3 \\
\hline 4 & Samodzielne stanowisko ds. sportu i rekreacji & 20 \\
\hline 5 & Urząd Stanu Cywilnego & 9 \\
\hline 6 & Wydział Edukacji & 29 \\
\hline 7 & Wydział Finansowy & 15 \\
\hline 8 & Wydział Geodezji i Katastru & 24 \\
\hline 9 & Wydział Gospodarki Komunalnej i Ochrony Środowiska & 24 \\
\hline 10 & Wydział Gospodarki Nieruchomościami & 46 \\
\hline 11 & Wydział Komunikacji i Transportu & 2 \\
\hline 12 & Wydział Kultury & 3 \\
\hline 13 & Wydział Polityki Mieszkaniowej & 17 \\
\hline 14 & Wydział Rozwoju Gospodarczego i Przedsiębiorczości & 31 \\
\hline 15 & Wydział Spraw Obywatelskich i Bezpieczeństwa & 20 \\
\hline 16 & Wydział Urbanistyki, Architektury i Budownictwa & 2 \\
\hline 17 & Wydział Zarządzania Kadrami & 9 \\
\hline 18 & Wydział Zdrowia i Spraw Społecznych & \\
\hline & Razem & \multicolumn{2}{|c|}{} \\
\hline
\end{tabular}

Źródło: Urząd Miejski w Słupsku, Biuletyn Informacji Publicznej. Pozyskano z http://bip.um.slupsk.pl/urzad_ miejski/procedury/ (2 grudnia 2015); opracowanie własne

Nadal funkcjonuje system kontroli zarządczej Urzędu Miasta i jednostek podległych. Roczne plany audytu i kontroli oraz sprawozdania z tych działań są dostępne do publicznej wiadomości i obejmują okres od 2013 roku. Natomiast dokumentacja przebiegu i efektów kontroli zarówno Urzędu Miasta, jak i jednostek podległych, obejmuje zestaw protokołów od 2003 roku.

Samorząd Słupska od ostatnich wyborów postawił sobie za cel wzmocnienie działań w czterech następujących obszarach: transparentność działalności Urzędu Miasta i jednostek podległych, edukacja, niepełnosprawni oraz przedsiębiorczość. Ma to znaleźć wyraz w uaktualnianej Strategii rozwoju miasta Słupska. Obecnie prowadzone są prace eksperckie. Organizowane są też konsultacje społeczne i debaty w poszczególnych obszarach tematycznych. 0 ile konsultacje społeczne były dotychczas prowadzone przy przygotowywaniu dokumentów strategicznych i stanowieniu aktów prawa 
miejscowego w obligatoryjnym zakresie, to odnosi się wrażenie, że nacisk kładziony na informację o tych działaniach i medialne zaangażowanie sprawiają, że obecnie występuje większe zainteresowanie społeczności lokalnej sprawami miasta.

W Słupsku bardziej intuicyjnie niż świadomie wprowadza się zmiany w kierunku zastosowania modelu nowego zarządzania publicznego oraz współzarządzania publicznego. Wyliczając instrumenty, które z najczęściej wymienianych w tych dwóch modelach zostały wdrożone w Słupsku, należy wskazać: zrządzanie strategiczne, wieloletnie planowanie finansowe, kontrolę zarządczą, budżet obywatelski (partycypacyjny). Jednak do nowoczesnego zarządzania miastem brakuje wdrożenia najtrudniejszych elementów, czyli budżetu zadaniowego oraz systemu zarządzania jakością.

Z rozmów z pracownikami Urzędu Miasta wynika, że chwilowo nie ma planów wprowadzenia przetestowanego wcześniej w Słupsku narzędzia do monitoringu jakości usług publicznych oraz że nie przywiązuje się do niego większej wagi. Jednocześnie trudno się oprzeć wrażeniu, że niełatwo wskazać przyczynę takiego stanowiska. Wdrożenie proponowanego przez Instytut Badań nad Gospodarką Rynkową systemu monitoringu wiąże się z nakładami finansowymi, co w przypadku niektórych samorządów lokalnych może być wielką barierą w doskonaleniu jakości usług publicznych.

\section{PodSUMOWANIE}

W obliczu przemian społeczno-gospodarczych o skali globalnej, regionalnej i lokalnej przed administracją samorządową w Polsce stoi zadanie zmiany sposobu podejścia do zarządzania jednostkami samorządu terytorialnego oraz właściwego kreowania funkcji administracyjnej jako ważnego czynnika rozwoju lokalnego. Według podejść teoretycznych, znanych na gruncie ekonomii i nauk o zarządzaniu, kształtuje się konieczność wdrażania instrumentów i narzędzi stosowanych w nowym zarządzaniu publicznym lub w jeszcze bardziej rozwiniętej jego formie - zarządzaniu współuczestniczącym. Z geograficznego punktu widzenia rozwój świadomego społeczeństwa obywatelskiego wymusza konieczność uwzględnienia czynnika humanistycznego przy tworzeniu funkcji administracyjnej. Podkreślają to współczesne koncepcje strukturalno-funkcjonalne rozwijane na gruncie geografii miast. Społeczność lokalna w coraz bardziej zróżnicowanych formach jest aktywnym odbiorcą usług publicznych, ale jest także ich kreatorem, świadomym swoich potrzeb i umiejącym wyraźnie wskazać ich zakres oraz poziom.

Usługi publiczne zajmują ważne miejsce w funkcjonowaniu administracji samorządowej. Ich realizacja, ale przede wszystkim wysoka jakość, mają wpływ na ocenę efektywności działań samorządu terytorialnego. W nowoczesnych modelach zarządzania doskonalenie jakości usług publicznych staje się jednym z priorytetowych celów wprowadzanych zmian. Wykorzystywane są do tego metody w postaci systemów monitoringu jakości usług publicznych, dające narzędzia ich powtarzalnego, stałego pomiaru oraz wnioskowania co do sposobów ich doskonalenia.

Jednym z takich systemów testowanych w Słupsku był Wzorcowy regionalny system monitoringu jakości usług publicznych i jakości życia. Dla administracji samorządowej ze stosowania takiego systemu wynikają jednoznaczne korzyści, które dotyczą 
usprawnienia działań administracji i dopasowania ich do potrzeb mieszkańców, zwiększenia przejrzystości funkcjonowania władz i uspołecznienia procesu zarządzania sprawami publicznymi. Dodatkowo istnieje możliwość porównania się z innymi jednostkami samorządu terytorialnego. Jednak pomimo ewidentnych korzyści wynikających z wdrożenia tej metody Urząd Miasta w Słupsku nie zdecydował się na kontynuowanie tego procesu.

Ocena działalności administracji samorządowej w zakresie monitoringu jakości usług publicznych nie wypadła korzystnie. Generalnie ciągle brakuje sprawnego, zintegrowanego z innymi działaniami samorządu systemu kontroli i zarządzania jakością usług publicznych. Dotychczas miasto funkcjonowało na bazie standardów ISO, dzięki którym wypracowane zostały procedury postępowania w najważniejszych sprawach publicznych. Od listopada 2015 roku wprowadzono nowy podział organizacyjny Urzędu, który wyraźnie odstępuje od kontynuowania standardów ISO. W zamian planuje się wypracowanie własnego modelu zarządzania i tym samym własnych standardów świadczonych usług publicznych. Posunięcie takie nie jest z natury rzeczy złe, ale w takim systemie trudno sklasyfikować jakość usług publicznych w porównaniu z innymi jednostkami samorządowymi. Utrudnia to w dużej mierze wyciąganie wniosków i poszukiwanie najlepszych rozwiązań na przykładach innych jednostek.

Pewne działania samorządu Słupska wskazują na intuicyjny sposób dążenia do ewolucji w stronę nowoczesnych modeli zarządzania. Z pewnością wprowadzane zmiany dotyczą zwiększenia transparentności działań Urzędu, zwiększenia znaczenia demokracji społecznej i włączenia społeczności lokalnej do aktywnego współrządzenia poprzez zwiększony nacisk na konsultacje społeczne. Jednak nadal dwa najważniejsze elementy: budżet zadaniowy oraz system zarządzania jakością usług publicznych pozostają do przemyślenia i wdrożenia. Instrumenty te są na tyle istotne, że to właśnie one dają ekonomiczne i społeczne efekty sprawności działania samorządu.

Istotny jest fakt, że największe miasta w Polsce już wdrożyły większość elementów nowoczesnego zarządzania. Poznań i Kraków są w tym zakresie najbardziej innowacyjne, gdyż funkcjonuje tam zintegrowany system zarządzania jednostkami samorządu terytorialnego. Inne duże miasta, jak Warszawa, Gdańsk, Szczecin, wdrożyły jeden z najtrudniejszych elementów zarządzania współuczestniczącego - budżet zadaniowy, ale nadal jest to niewielka część całego procesu efektywnego zarządzania miastem. Perspektywiczne efekty i konieczne warunki opisują teoretycznie: ekonomia behawioralna i geografia funkcjonalna.

\section{Literatura}

\section{References}

Bosiacki, A., Izdebski, H., Nelicki, A., Zachariasz, I. (red.) (2010). Nowe zarzq̨dzanie publiczne i public governance $w$ Polsce i Europie. Warszawa: Liber.

Czerwińska, M., Gajdasz, J., Hildebrandt, A., Kopeć, K., Kpuc-Muszyńska, B., Michalski, T., Nowicki, M., Susmarski, P., Tarkowski, M. (2014). Jak zaprojektować i wdrożyć system monitoringu jakości usług publicznych i jakości życia? Podręcznik wdrażania. Gdańsk: Instytut Badań nad Gospodarką Rynkową.

Domański, R. (2000). Miasto innowacyjne. Warszawa: PWN.

Dryglas, D. (2014). Proces budowy strategii zarządzania zmianą gospodarczą na przykładzie Krynicy-Zdrój. Prace Komisji Geografii Przemysłu Polskiego Towarzystwa Geograficznego, 28, 38-58. 
Duda, J., Jeżowski, A., Misiąg, W., Nowak, B., Szlachta, J., Zaleski, J. (2004). Mierzenie ilości i jakości usług publicznych jako element Programu rozwoju instytucjonalnego. Warszawa: Instytut Badań nad Gospodarką Rynkową.

Glińska, E. (2009) (2016, 14 stycznia). Ekspertyza dotycząca tematu: Monitorowanie jakości usług publicznych, m.in. poprzez wspieranie tworzenia wskaźników typu quality of governance, quality of life o zasięgu krajowym, wspieranie upowszechniania tzw. indeksów dobrej gminy oraz benchmarking wpisanego w Plany Działań IP/IP2 na 2009 r. Pozyskano z https://www.wup.pl/images/uploads/VII. FUNDUSZE_EUROPEJSKIE/Innowacyjnosc_i_ponadnarodowosc_-_aktualnosci/ekspertyzy/dd.Ekspertyza_Temat\%C3\%B3w_projekt\%C3\%B3w_innowacyjnych_-_us\%C5\%82ugi_publiczne.doc

Halcombe, R.G. (1997). A Theory of the Theory of Public Goods. The Review of Austrian Economics, 10(1), $1-22$.

Hausner, J. (2002). Od idealnej biurokracji do zarządzania publicznego. W: J. Hausner, M. Kukiełka (red.). Studia z zakresu zarzq̨dzania publicznego, t. II. Kraków: Akademia Ekonomiczna w Krakowie, 51-67.

Izdebski, H., Kulesza, M. (2004). Administracja publiczna, zagadnienia ogólne. Wydanie 3. Warszawa: Liber.

Kaczmarek, T. (2005). Struktury terytorialno-administracyjne i ich reformy w krajach europejskich. Seria Geografia, 70.

Kowalczyk, L. (2008). Współczesne zarządzanie publiczne jako wynik procesu zmian w podejściu do administracji publicznej. Zeszyty Naukowe Wałbrzyskiej Wyższej Szkoły Zarządzania i Przedsiębiorczości, 1, 4-14.

Kożuch, B., Kożuch, A. (2011). Usługi publiczne. Organizacja i zarzq̨dzanie. Kraków: Uniwersytet Jagielloński.

Krynicka, H. (2006). Koncepcje nowego zarządzania w sektorze publicznym (New Public Management). Studia Lubuskie, 2, 193-202.

Maik, W. (1992). Geografia miast. Toruń: Uniwersytet Mikołaja Kopernika.

Marchewka-Bartkowiak, K. (2014). Nowe zarządzanie publiczne. Infos. Zagadnienia Społeczno-Gospodarcze, 18(187).

Michalski, T. (2013). Pomorskie doświadczenia we wdrażaniu systemu mierzenia jakości usług publicznych. Gdańsk: Instytut Badań nad Gospodarką Rynkową.

Ochnio, M. (2012). Nowe zarządzanie publiczne (New Public Management) - podstawowe cechy modelu. Jego zastosowanie w Polsce. Warszawa: Instytut Zmian, Working Paper, 1.

Parysek, J.J. (1997). Podstawy gospodarki lokalnej. Poznań: Wydawnictwo Naukowe Uniwersytetu Adama Mickiewicza.

Raport - krajowe i zagraniczne doświadczenia w zakresie badania jakości usług publicznych i jakości życia (2011, wrzesień). Gdańsk: Instytut Badań nad Gospodarką Rynkową.

Rogala, P., Kusterka-Jefmańska, M., Chojecka, J., Koch-Mitka, J. (2012, lipiec). Raport: Opis koncepcji, metodyki oraz narzędzi badań wskaźników jakości życia i wskaźników jakości usług publicznych dla jednostek samorządu terytorialnego na przykładzie Krakowa i Poznania, w ramach projektu „Monitorowanie jakości usług publicznych jako element zintegrowanego systemu zarządzania jednostkami samorządu terytorialnego". Kraków-Poznań.

Suliborski, A. (2001). Funkcje i struktura funkcjonalna miast. Studia teoretyczno-empiryczne. Łódź: Uniwersytet Łódzki.

Suliborski, A. (2010). Funkcjonalizm w polskiej geografii miast. Studia nad genezq i pojęciem funkcji miast. Łódź: Wydawnictwo Uniwersytetu Łódzkiego.

Szajnowska-Wysocka, A. (1995). Podstawy zorganizowania miast konurbacji górnośląskiej. Katowice: Uniwersytet Śląski.

Szymańska, W. (2015). The role of the administrative functions in the development of the city in Poland (by example of degraded towns). W: W. Szymańska (red.). Regional Development and Public Administration in the Context of General Tendencies of XXI century. Słupsk-Kharkiv: Publishing House ADNDU, 5-18.

Wojtasiewicz, L. (1997). Czynniki rozwoju lokalnego - nowe ujęcie metodologiczne. W: W. Maik (red.). Problematyka rozwoju lokalnego $w$ warunkach transformacji systemowej. Biuletyn Komitetu Przestrzennego Zagospodarowania Kraju PAN, 177, 7-18.

Wioletta Szymańska, dr, Akademia Pomorska w Słupsku, Wydział Matematyczno-Przyrodniczy, Instytut Geografii i Studiów Regionalnych. Doktor nauk o Ziemi, specjalność: geografia społeczno-ekonomiczna. Główne obszary zainteresowań: geografia osadnictwa, funkcjonalizm w badaniach geograficznych, struktury wewnętrzne miast i ich przeobrażenia, problemy społeczne w geografii, percepcja i waloryzacja przestrzeni 
miejskiej, społeczne aspekty rozwoju jednostek osadniczych. Autorka ponad 60 publikacji naukowych oraz redaktor naukowy 4 monografii.

Wioletta Szymańska, Ph.D. in Earth Sciences, specializing in socio-economic geography. Main areas of interest: geography of settlement, functionalism in geographical research, internal structures of cities and their transformation, social problems in geography, perception and valorization of urban space and social aspects of development of settlement units. Author of over 60 scientific publications and editor of 4 monographs.

\section{Adres/address:}

Akademia Pomorska w Słupsku

Wydział Matematyczno-Przyrodniczy

Instytut Geografii i Studiów Regionalnych

ul. Partyzantów 27, 76-200 Słupsk, Polska

e-mail: wioletta.szymanska@apsl.edu.pl 